\section{The role of the church in the birth and nurture of a new nation}

M Dandala

(University of Pretoria)

\section{ABSTRACT}

\section{The role of the church in the birth and nurture of a new nation}

Bishop Mvume Dandala, in his inaugural lecture as honorary professor at the Faculty of Theology, University of Pretoria, describes the challenges awaiting the churches in the new South Africa. He does it by defending five theses: (1) It takes strong visionary leadership to lay foundations for reconciliation; (2) Ground base support and initiatives are critical for the success of reconciliation; (3) Social transformation, fairness and justice must be understood as an intrinsic fabric of reconcilia tion; (4) Reconciliation is not possible where the contending factions do not have a common understanding of the truth; (5) A healthy memory of the past is essential for a reconciled/reconciling future.

\section{THE CHALLENGE}

Writing in the City Press Sunday paper, about South Africa losing the bid for the 2006 Soccer World Cup, Koos Bekker says:

"If South Africans can bury their past and work together we could build a highly successful country. No one else cares for us - let us then help each other."

In the same article, Bekker continues:

"Some Whites believe Europe will rush to their rescue if a civil war broke out, because they are pale skinned. Some Blacks believe that Europe must compensate for the exploitation of the past."

He then concludes:

"Truth is, Europe feels no link with South Africans of any colour... Countries have no friends or enemies, just interests... South Africa Incorporated has the infrastructure to compete in the open market. What is holding us back? Nothing, except the historical divide... We are still prisoners of our divided past... But on
Thursday (6 July) in Zurich, when the circus was over and our people reacted with dignity, when the South African team did not fall apart, but went back to the hotel as a unit, sang the national anthem together... then I thought... our rainbow nation can maybe just work... If we can bury the past and work together as a team who knows - we could just build a highly successful country."

It is in this spirit and belief that I have accepted the honour bestowed on me by the University of Pretoria to serve for a period as Honorary Professor of Theology.

The divergence of our backgrounds must be brought together to fashion a path that will allow South Africans together, to put their destiny in their own hands. The role of the Church in the birth of South Africa was significant. Its continued nurture of this fragile infant remains a critical challenge. For me, there is no better theological terminology that could express this challenge more than the quest for reconciliation. The Truth and Reconciliation Commission under the leadership of Emeritus Archbishop of Cape Town, the most Reverand Desmond Mphilo Tutu, has done much to expose the truth concerning our past. The challenge that we must all work on is to make the second part of the task of the Commission a reality, thereby effecting reconciliation in our land. The Church, and centres of learning like this University must be unashamedly in the forefront. Chief among our responsibilities must be constant reflections on what makes for reconciliation, so that we produce leaders who will reverse the history of division and suspicion among our people.

As my own response to this challenge I propose the following theses.

\section{FIVE THESES}

Thesis 1: It takes strong visionary leadership to lay foundations for reconciliation

This asks for a leadership recognises the truth that dialogue is not cowardice. It is ever so easy to forget the intensity of the dialogue that led to the birth of a liberated South Africa. Starting with the conversations of Nelson Mandela in prison with the then Minister of Justice Kobie Coetzee; the intense exchanges between business leaders and P W Botha at the Carlton Hotel; the visits of business leaders to Lusaka to dialogue with the A N C; the Congress for a Democratic South Africa's (CODESA) meetings between the liberation movements and the De Klerk government; the National Peace Accord; the South African people determinedly sought to map out for themselves the values on which they wished to see their country built.

ISSN 1609-9982 = VERBUM ET ECCLESIA Jrg 22 (1) 2001 
The key lesson from this array of activities, I believe, is that those who are entrusted with the responsibility of leading people must do so determinedly in ways that chart the way to a reconciled society. Reconciliation is not the kind of goal that the majority of people easily embrace or democratically vote for as the path and goal to pursue. It often takes focussed and courageous leadership to do so. A few examples from South Africa:

- The business leaders who travelled to Lusaka to meet the African National Congress (ANC) did so in the face of the unbridled wrath of PW Botha's apartheid regime. Yet they had to make a choice for the possibility of a liberated and reconciled nation. They experienced not only the government's wrath, but also that of their colleagues in business, who could not fathom any possibility of dialogue with what they considered to be a monster, the demonic, communist African National Congress.

- I constantly wonder how many of us could have taken the risk that former President Mandela took while he was imprisoned on Robben Island, to singlehandedly open negotiations with the enemy. Without bold leadership, reconciliation remains elusive. With the advantage of hindsight, knowing what has since happened, we may easily underestimate the dangers and humiliation that $\mathrm{Mr} \mathrm{Man}$ dela's actions could have brought him. The worst thing that could happen in anyone's life is to be disowned by your own people, the ones you have given your life for. It could easily have happened to Mr Mandela.

Former Premier of Gauteng, Mr Tokyo Sexwale tells of their first visit to Victor Verster Prison to see Mr Mandela after he had been moved there by the regime. Tokyo says that when they saw that Mr Mandela's new residence even had a pool, they wondered if he had sold out. Mr Mandela himself tells of the anger of his colleagues in prison, the likes of Mr Govan Mbeki and Mr Raymond Mhlaba on hearing that he had quietly started talks with the enemy. At that point his nerve could have deserted him. But he stood firm, for a vision of a liberated and reconciled nation.

- Putting together the CODESA and National Peace Accord initiatives and sustaining them, required strong and persistent leadership. Not once, but many times we held our breath, convinced that the CODESA talks would fall apart. Only determined and visionary leadership saved these processes from crashing. The furious exchanges between the ANC and the Nationalist Party, the walk out of the Pan Africanist Congress, and the uneasy participation of the Inkatha Freedom Party (IFP) in the National Peace Accord, all point to the fragility of the process. Yet strong and visionary leadership, or dare I say, patriotic leadership saved the day.

My first thesis, therefore, is that reconciliation is not an easy path to follow or goal to pursue; it takes strong and visionary leadership, supported by imaginative and consistent strategies, to nurture and market it. Indeed, it must be said that were it not for a determined marketing drive at this time, it is in my mind uncertain that we could have gone as far as we did.

\section{Thesis 2: Ground based support and initiatives are critical for the success of reconciliation}

The wars of the early 90's made themselves felt by ordinary South Africans. The dying and killing of our people reared its ugly head in the streets of our townships: in Khumalo Street in Thokoza, in Marshall Street in Johannesburg, in Mpumalanga Hammersdale, in Holomisa squatter camp, in Boipatong, in Selby and Jeppe Hostels in Johannesburg. Ordinary people died at the hands of people they knew, people they had lived and danced with. No amount of National Peace Accord or CODESA could transform the lot of these people. It took ordinary South Africans to echo in their lives the courage for the great cause of reconciliation that they had gleaned in the character of their leaders. The story of these ordinary South Africans must still be told one day. There is a very real danger that it will be forgotten.

It was an ordinary migrant worker, Jacob Dhlomo from Jeppe Hostel who, one day, took his life in his hands and decided that he would walk alone to their rival Selby Hostel to deliver a letter from his senior fellow residents at Jeppe, to ask his opponents at Selby how long they would continue killing each other for reasons none of them fully comprehended. From that gutsy initiative a Hostel Peace and Reconciliation Initiative was launched, with the purpose of seeking to foster new relationships and reconciliation among the Hostel residents in the Reef. At its highest point, this initiative involved no less than 50,000 people from 32 hostels in and around Johannesburg. The residents decided that for them, primarily, reconciliation would be inspired by the values they had been brought up with, commonly known in South Africa as UBUNTU - value of personhood. They agreed that the Bible and Christian Faith would be a support system. But to embrace everybody they needed to go beyond the often exclusive church culture. Using as a clarion call Nehemiah's decision to go and rebuild the broken down walls of Jerusalem, they committed themselves to put reconciliation as the foundation on which the new South Africa would be built. To entrench this vision among their 
communities, they decided on a programme whose cornerstones would be the following values and actions:

\section{Forgiveness}

This was the most difficult part, as the residents often contended that everything they did to one another was communally based, and therefore not primarily a responsibility of any single individual.

I am still surprised at how effectively this worked. I had an opportunity to share with these people in joint activities after the declaration of their initiative. Not only would they dance together, but they recalled freely in the presence of each other the instances of conflict. They themselves retold them, many a time commending the gallantry of individuals from the opposing side. Yet on the other hand, whenever an outside group tried to replay conflict in the form of stage drama, they all took extreme exception. I have never been able to fully understand this, except to say that for them the replay by an outsider was often interpreted as a judgement on them laced with the traditional disdain that South Africans have over the years displayed towards hostel residents. The theory they built this on was a traditional Nguni saying: AYITHOBANE IZINGOZI - My enemy has a responsibility to offer me a balm to my injuries. This is what it means to be human.

\section{Let all protect each other [Mayivikelane]}

This was an incredible commitment, to risk one's life for the sake of one' enemy. The profundity of this commitment was that, whilst for them it primarily meant that if I am drunk and I find myself in your territory, you will not only refrain from harming me, but you will also ensure that nobody harms me. The upshot of this commitment was to form a barrie against the third force. No one will turn me against you for whatever reason. As a result of this commitment they could pre-empt attacks in trains and forestall them.

\section{Let all respect each other (Mayihloniphane)}

For the communities that for many years had been set against each other on ethnic grounds, this was an exciting principle. There are many myths in South Africa about various ethnic groupings that Apartheid had nurtured and fed. A deliberate decision was taken to develop ways by which admiration for ethnic variety would be nurtured and harnessed for the purpose of trying to highlight common nationhood. Exchanges in cultural education were mooted and encouraged. It is somewhat sad that this has since not been developed further. The strongest impact of this commitment was in relation to the young people in the surrounding communities like SOWETO, where hostility between communities and hostel residents had often come out in the open, resulting in serious conflicts. Opportunities were created for room, to get to know each other, with good results.

\section{Commitment to self-transformation}

Since the church was one of the major support structures to this initiative, evangelistic opportunities were used creatively. These took place hand in hand with training programmes for transformative leadership. Together they focussed on the need to develop social activities through which their energy would be channelled. Sport was crucial, and it enhanced the potential of positive engagement.

Furthermore, this commitment led to engagement with people that they disagreed with or did not fully understand or trust. One such instance was a session held between the Hostel supporters of Inkatha Freedom Party and the leadership of the Church in the persons of Archbishop Desmond Tutu, Bishop Khoza Mgojo and Bishop Stanley Mogoba. Openness and transparency became a bedrock for a new relationship that developed between these people. One of the most memorable days for South Africa was when Archbishop Desmond Tutu visited the war torn areas of every side in the East Rand with a message of peace and reconciliation.

\section{Thesis 3: Social Transformation, fairness and justice must be under-} stood as an intrinsic fabric of Reconciliation

Many days were spent many days in the company of young South Africans in the war torn areas of the East Rand, people who had sacrificed their future for the higher ideal of freedom. Many of them left schooling in their early years of learning, to become soldiers for freedom. With freedom having been achieved, many came to be considered, in terms of old Apartheid language, "superfluous appendages" to society. Wider society used terms to describe and cast them in the category of the uncared for. The lost generation, we called them

These were the ones who bore the brunt of the chilly winter nights of Apartheid. We dared not walk towards the beckoning rays of sunrise without them. Asked if they were prepared to lay down their weapons of war, they posed a legitimate and in fact biblical question: "If you take these guns from us, what will you put in our hands in return"? The greatest temptation was to think that all they were looking for was money in exchange for guns. That was the kind of society we were. No, they were looking for something more profound. They wanted their life back in exchange. They were looking for opportunity. We dared not deny them this. Those of us who had opportunity were quick to offer them an opportunity to become policemen, security guards or some such 
communities, they decided on a programme whose cornerstones would be the following values and actions:

\section{Forgiveness}

This was the most difficult part, as the residents often contended that everything they did to one another was communally based, and therefore not primarily a responsibility of any single individual.

I am still surprised at how effectively this worked. I had an opportunity to share with these people in joint activities after the declaration of their initiative. Not only would they dance together, but they recalled freely in the presence of each other the instances of conflict. They themselves retold them, many a time commending the gallantry of individuals from the opposing side. Yet on the other hand, whenever an outside group tried to replay conflict in the form of stage drama, they all took extreme exception. I have never been able to fully understand this, except to say that for them the replay by an outsider was often interpreted as a judgement on them laced with the traditional disdain that South Africans have over the years displayed towards hostel residents. The theory they built this on was a traditional Nguni saying: AYITHOBANE IZINGOZI - My enemy has a responsibility to offer me a balm to my injuries. This is what it means to be human.

\section{Let all protect each other [Mayivikelane]}

This was an incredible commitment, to risk one's life for the sake of one' enemy. The profundity of this commitment was that, whilst for them it primarily meant that if I am drunk and I find myself in your territory, you will not only refrain from harming me, but you will also ensure that nobody harms me. The upshot of this commitment was to form a barrie against the third force. No one will turn me against you for whatever reason. As a result of this commitment they could pre-empt attacks in trains and forestall them.

\section{Let all respect each other (Mayihloniphane)}

For the communities that for many years had been set against each other on ethnic grounds, this was an exciting principle. There are many myths in South Africa about various ethnic groupings that Apartheid had nurtured and fed. A deliberate decision was taken to develop ways by which admiration for ethnic variety would be nurtured and harnessed for the purpose of trying to highlight common nationhood. Exchanges in cultural education were mooted and encouraged. It is somewhat sad that this has since not been developed further. The strongest impact of this commitment was in relation to the young people in the surrounding communities like SOWETO, where hostility between communities and hostel residents had often come out in the open, resulting in serious conflicts. Opportunities were created for room, to get to know each other, with good results.

\section{Commitment to self-transformation}

Since the church was one of the major support structures to this initiative, evangelistic opportunities were used creatively. These took place hand in hand with training programmes for transformative leadership. Together they focussed on the need to develop social activities through which their energy would be channelled. Sport was crucial, and it enhanced the potential of positive engagement.

Furthermore, this commitment led to engagement with people that they disagreed with or did not fully understand or trust. One such instance was a session held between the Hostel supporters of Inkatha Freedom Party and the leadership of the Church in the persons of Archbishop Desmond Tutu, Bishop Khoza Mgojo and Bishop Stanley Mogoba. Openness and transparency became a bedrock for a new relationship that developed between these people. One of the most memorable days for South Africa was when Archbishop Desmond Tutu visited the war torn areas of every side in the East Rand with a message of peace and reconciliation.

\section{Thesis 3: Social Transformation, fairness and justice must be under-} stood as an intrinsic fabric of Reconciliation

Many days were spent many days in the company of young South Africans in the war torn areas of the East Rand, people who had sacrificed their future for the higher ideal of freedom. Many of them left schooling in their early years of learning, to become soldiers for freedom. With freedom having been achieved, many came to be considered, in terms of old Apartheid language, "superfluous appendages" to society. Wider society used terms to describe and cast them in the category of the uncared for. The lost generation, we called them.

These were the ones who bore the brunt of the chilly winter nights of Apartheid. We dared not walk towards the beckoning rays of sunrise without them. Asked if they were prepared to lay down their weapons of war, they posed a legitimate and in fact biblical question: "If you take these guns from us, what will you put in our hands in return"? The greatest temptation was to think that all they were looking for was money in exchange for guns. That was the kind of society we were. No, they were looking for something more profound. They wanted their life back in exchange. They were looking for opportunity. We dared not deny them this. Those of us who had opportunity were quick to offer them an opportunity to become policemen, security guards or some such 
gun related opportunity. They looked us in the eye disdainfully, as if to say, "How dare you call it opportunity when you have offered us no choice". We stood back, and asked them to chart the path they wished to take to the sunrise of the new South Africa.

They spoke. From Thokoza they spoke. From Vosloorus, from Katlehong. They could still dream and see visions. How dare we quench the flickering flame of ambition from their eyes.

- They asked for healing. "The wounds are deep", they said. Forgiveness is nigh impossible. It was their fathers they had lost. Their mothers, their brothers, their sisters. Their corpses torn by the scavenging dogs of oppression and war. Yet they longed for their wounds to be dressed; to learn to forgive, to learn to live again.

Their plea was that counselling sessions should be taken out of the pastors' study rooms and church vestries to Khumalo Street, to Tamboville, where the tears of their mothers had flowed with no one to dry them.

- They asked for a hand to hold theirs as they stumbled like little babes, learning the skills of life afresh. They said, "Help us turn our eyes away from war and endless death. Give us excitement and purpose for living". The Reconstruction and Development Programme was a dream they cherished; yet a nightmare that was to condemn them unless they were given basic rudimentary skills that would make them part of the rebuilding of the nation. And so they said, "It is not only in the security forces that we want to go. Walk with us, allow us a taste of the richness of diversity. Some of us may yet teach those who come after us, the skills of handling life; some of us have the fire in our bellies to still make us champions and commanders of a new economy. Yes, some of us may be the custodians of safety and stability. But share part of your opportunity with us, so that ours may not be an eternal sentence to oblivion".

Some privileged people asked: How can a 14 year old, who had mowed down dozens of people with an AK47 still go back to school? How could an 18 year old who had bailed out of the classroom in his/her 3 rd year at school still seek for opportunities lost? We have not successfully answered these questions. And they still stare us in the face as many of these youngsters turn to crime. South Africa is still challenged to be innovative, and to bend normal practices. Conventional education has to bend, not merely for its pride, but also for the pride of South African generations to come. The classroom still has to be taken to the streets. It is not only Thokoza, Vosloorus and Katlehong. It is Soweto, KwaMashu in Durban, New Brighton in Port Elizabeth and throughout the valleys and hills of beautiful South Africa. There have been laudable efforts, but much more is still needed.

Our young spoke and dreamt of the day they would be counted among job creators. They organised themselves to clean their townships long-abandoned as biblical lepers. Yet those who have power, as soon as they had access to the townships, patted them on the shoulders in some paternalistic fashion and then proceeded to share the spoils as they awarded each other contracts to offer professional cleaning services to the wretched townships. It is at these that the prophetic voice of the Church must shout out loud, when the new South Africa is to have meaning to all our people. Reconciliation cannot take place where there is no concerted effort to correct the wrongs of the past.

Thesis 4: Reconciliation is not possible where the contending factions do not have a common understanding of the truth

One of the most startling factors about South Africa was always the divergence in the understanding of truth among South Africans, and particularly black and white South Africans. The greatest contribution of the Truth and Reconciliation Commission in my view was the opportunity it afforded South African people to have a glimpse at their common life through a common lense. Some of the most devastating pieces of legislation in our past were those of the group areas act and separate education systems. These effectively denied the South African people opportunities to know one another and to grow together. As a result, they formed fantastic ideas about one another that were more often than not far from the truth.

Things unearthed by the Truth and Reconciliation Commission show the depth of pain that our society has inflicted on her people. It challenged us with the need to transform attitudes - especially in white communities. Attitudes that have been nurtured over a long period, skewed in their understanding of what it means to be human, have to be transformed.

The white community in general was shell shocked at the revelations of the Truth and Reconciliation Commission; things done in their name, things defended by most of them without wanting to know what they were defending. In a sense many white people surrendered into the hands of the Apartheid regime their rights to decide and know. They made a choice not to know. Suddenly through the Truth and Reconciliation Commission they found themselves confronted with the truth. Many South African white people were upset when Apartheid was compared to Nazism. Suddenly with the Truth and Reconciliation Commission they

ISSN 1609-9982 = VERBUM ET ECCLESIA Jrg 22 (1) 2001 
found that much that is known about Nazism is comparable to Apartheid: people killed in prison and fed to crocodiles, schemes for black women to be sterilised, Aids being used as a military strategy, and the use of chemical warfare against its own people. The tendency to say that that was yesterday, now let us move on, fails to understand that we can't just move on. There are specific things that South Africans will have hopefully learnt to face and tackle together for the new to happen. And the Church must endeavour to walk ahead of the people offering leadership in this regard.

- Strategies for reparation have to be effectively developed. In the Methodist Church of Southern Africa we have taken a decision to establish a Millennium Mission Foundation. All our members are requested to contribute towards this fund according to their capability. Some White Methodists have reacted negatively to what they see as reparation taxation. I think this is sad, for if it is taxation it is not exclusively directed at white people. It is a challenge to all Methodist people including the poor. South Africans must be encouraged to embrace approaches that will involve them all together in the work of reparation. There is a sense in which business in South Africa is already doing this in its Business Trust. Individual South Africans must be encouraged to find ways of doing this as well.

- In South Africa reconciliation must express itself in genuine racial integration. The key challenge to the Christian community is for the establishment of authentic racially integrated congregations, rooted in the African context, sharing their faith, culture and resources, with a commonly driven programme to heal the wounds of Apartheid. We must not allow churches to be comfortable where their congregations are comfortable in exclusivity.

- We have to facilitate a way whereby those who were perpetrators could make up for their actions in ways that would lead to their healing. We dare not underestimate the extent to which men and women who were basically good people were turned into monsters by a system that was callous and basically inhuman. Many of those people today are carrying a sense of guilt that they know not how to cleanse themselves of. The Gospel of Christ primarily seeks to set such people free, and allow them the dignity again to move among people, even those they had hurt, and say with confidence, "I was blind, but now I see" (Jn 9:25). It will, of course, take processes that are lengthier than the Truth and Reconciliation Commission to arrive at that point. It will require communities and all civic structures to take each of such people by the hand, and lead them on a path to their healing. Some sections of the church in South Africa are blind to this need, and their consistency might easily make us miss the opportunity to offer a reconciliation ministry that is essential to South Africa.

Issues such as fair distribution of resources cannot be treated merely as political factors. When we talk about equitability at the level of public schooling, we tend to see this as implying a drop in the educational standards. We have not reached a point where we recognise these as sharing with one's brother or sister who suffered because some were privileged. We have to find ways to help our people to find joy in sharing as a way of saying let us find reconciliation together.

If it is only the formerly oppressed who will seek to exact that out of those who had benefitted, then it ceases to be a path to reconciliation. It becomes, instead, a spiral of fighting with one another. I believe that this is a critical role for bodies like Churches to help people who come from the communities that consciously or unconsciously benefitted from Apartheid to actually say how best they can share with other people; how best they can be helped to actually find honour, and how best to discover nobility in learning to share with others.

\section{Thesis 5: A healthy memory of the past is essential for a reconciled/} reconciling future

We have to encourage those who were victims to forgive. Forgiveness does not come easily. Yet forgiving another person sets both the victim and the perpetrator free. To refuse to forgive is to devalue the sacrifice of so many who in the fashion of Christ, gave of their lives freely, in order that our nation will be free. To ask that of the victims is not to excuse us collectively of our obligation to minister to them. We are called to support them and do everything in our power to ensure that the burden they carry as families for the sake of our nation is made easier.

Many of our people, particularly young people, died at the hands of the Apartheid regime. We can be very angry that they died so young, and find it very difficult to be reconciled with people who supported the old regime. We cannot arrive at reconciliation if we do not help the communities of those who were struggling against injustice to understand and accept that the lives of their loved ones were not taken from them.

Rather they themselves, laid their lives down. In other words, rather than allowing ourselves to act like something could be done that could make up for their lives, we need to be working on the development of processes where we can say together: here are our heroes who laid their lives down for a higher goal and an honourable goal. 
I think that South Africa's fear of creating heroes is robbing us of an opportunity to focus on what those heroes were giving their lives up for. Since freedom in South Africa arrived, I have come to the conclusion that we have decided, as South Africans, to get on with life as if all were well. Yet it is not so. I think all will be well, not only for us but also for our young people, if there are processes that highlight the high goals of honour, the noble goals for which our people laid down their lives.

Our people laid down their lives for the kind of Nationhood where freedom and reconciliation will be the cornerstones. Talking about Nationhood, Pope Paul 11 says:

Belonging to a nation of fathers, mothers and forebears reaches deep into the conscience of a person, requiring truth about oneself (Man of the Century P.267.)

One does not always get a sense that we have, as a nation reached a point where our people can claim that deep sense of Nationhood from which flows streams of reconciliation.

But even more challenging is the task of healing the memory of those whose sons died in wars that nobody in their families believed in. Many a White family, I believe, was pushed to a position where their sons were conscripted into a war that they were misled to believe was justifiable.

The revelations of the Apartheid atrocities must be leading many a White South African family that lost a son in these wars to say that their children were victims of an evil system. Somehow a response to this pain must be found, for the future is dependant on healthy memories.

\section{THE CHALLENGE TO KEEP OUR STORY ALIVE}

If it were correct to claim that nationhood and reconciliation required a deep sense of self understanding that involved generations and their struggles, I would argue for us to keep our people's memory alive to the struggles that have marked our journey to nationhood.

One is not convinced that we have adequately explored the ways by which we can develop reserves of memory for our people in South Africa. Indeed, the Western classical way of doing this is by recording it in books, and maybe set aside special holidays like the Independence day in July in the USA. A context like ours needs more than this to keep the memory alive. We need a process that will not only tell the results of the struggles, but also knit together the varying strands of the struggle in ways that will make it possible for us to claim a common nationhood. For instance, in spite of the many ideological differences that marked our struggle, the many let downs that may have caused bitterness between people who were on the same side fighting our oppression, the quest for freedom was a common thread that held them on the same side, be it tenuously. We should, therefore, be searching for ways by which we, together with generations to come, will so communicate our story that we are able to claim the Makgathos, the Mahabanes, the Luthulis, the Mandelas, the Sobukhwes, the Josephs, the Slovos, the Bikos, and many other such, as our forbears who became foundational to the birth of our nationhood.

The other aspect is that of the actual suffering endured by our people for many generations. In his inauguration address the first President of the Republic of South Africa, declared that "never again will South Africa go through what it has experienced in its history of oppression".

This statement needs to be etched in what I call the collective memory of our nation. The question is, how can this be done? Please allow me to suggest three ways:

Firstly, it will be done as the religious communities learn how to incorporate these truths into their regular practice of teaching and liturgy. This will of course require, first a bold effort by them at determining whether they really believe there was a hand of the Almighty, in the act of the birth of our Nationhood, and if that hand will assist in facilitating reconciliation.

Secondly, we have to find ways of communicating the commonality of the people of the Republic of South Africa. We waged the struggle on the understanding that whilst there may be divergencies among us, like the different languages, basically we are one people. We were not one, merely because we had a common enemy. We stressed our unity, precisely because we believe that the different gifts are given to us so that we can enrich one another. Our immediate political past stressed our differences as points of divine imperatives for our disunity. No effort must be spared to create opportunities for our people to experience each other in ways that will bind them in their pursuit of the future. This is fundamental in the quest for common nationhood and reconciliation.

Thirdly, we must develop a common approach to the challenge for the transformation of our public life. Two important documents, in my view, have not yet been engaged adequately by the public of South Africa, and particularly the religious communities. These are the Bill for Human Rights, and the Constitution of the Republic. These two documents could be pivotal in the development of a reconciling society. One does realise that the educated communities may be aware of these documents, and some may even have engaged them. But I am doubtful. It would seem to me that if we are really keen on developing an ethos that will form the basis for reconciliation and debate on the values and standards that we may wish to observe in South Africa, it is these two documents that must form the basis of our communication. They have the

ISSN 1609-9982 = VERBUM ET ECCLESIA Jrg 22 (1) 2001 
capacity to give a common normative truth to our society that would be the primary governing truth. Within the common Constitution and common Bill of Rights we could be able to develop perspectives that will serve as a means for the exposition and undergirding of the common good. Within these documents we will find that there is enough to assert the primacy of the ethical over the technicals; of the person over things and thus of a reconciling society.

\section{CONCLUSION}

There is no doubt in my mind as to the immensity of the task that is ahead of us. A new nation has a task of laying the foundations that will sustain reconciliation for many generations to come. The leadership of the new nation cannot avoid this responsibility. The willingness to set communication lines that will allow every citizen who so desires to contribute in this process must be encouraged. The strength of this for now is that there is a chance to work not as adversaries. We can be on the same side. If our communication now on these matters of national values could be open, honest, creative and vibrant, we might build a secure future on the foundations of those who correctly understood truth as the only sure base for a reconciled and reconciling future.

\section{Consulted literature}

City Press, July 9, 2000: Koos Bekker, Managing Director of Naspers, "Let's unite and put our destiny in our own hands".

IDASA, 1988.

IDASA, October 1987.

The National Peace Accord, signed September 14, 1991.

CODESA I, December 21, 1991.

Mandela, Nelson, Long walk to Freedom, Macdonald Purnell (Pty) Ltd, Randburg 1994, 519.

CODESA, 1991.

The National Peace Accord, 1991.

Minutes of the HPI - Central Methodist Mission, November 20, 1992.

Man of the Century, p 10-11. 